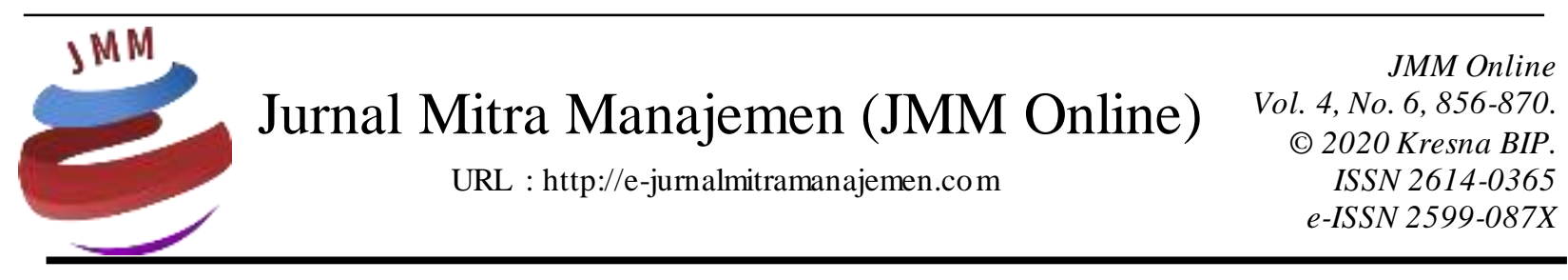

\title{
PENERAPAN CUSTOMER SATISFACTION INDEX (CSI) DAN IMPORTANCE PERFORMANCE ANALYSIS (IPA) PADA KUALITAS PELAYANAN GOJEK (STUDI PELANGGAN DI KOTA BANDUNG)
}

\author{
Hasna Rahagi Sampurno 1), Osa Omar Sharif 2) \\ Universitas Telkom
}

INFORMASI ARTIKEL

Dikirim : 22 April 2020

Revisi pertama : 11 Juni 2020

Diterima : 12 Juni 2020

Tersedia online : 01 Juli 2020

Kata Kunci: Gojek, Kualitas Layanan, Kepuasan Pelanggan, Customer Satisfaction Index (CSI), Importance Performance Analysis (IPA)

Email : hasnaarahagi@gmail.com ${ }^{1)}$, osaomarsharif@telkomuniversity.ac.id ${ }^{2)}$

\begin{abstract}
ABSTRAK
\end{abstract}
Saat ini Kota Bandung tercatat sebagai kota termacet se-Indonesia melebihi Kota Jakarta dan Kota Surabaya. Terobosan terbaru pada sarana transportasi yang muncul di era masa kini sebagai alternatif transportasi untuk menghindari kemacetan adalah pemesanan jasa transportasi melalui aplikasi online seperti Gojek. Namun belakangan ini banyak keluhan yang diadukan oleh pelanggan di social media mengenai kualitas layanan Gojek. Keluhan tersebut dapat menjadi masalah yang serius dan berdampak buruk bagi Gojek. Sampel yang digunakan pada penelitian ini adalah 400 responden, dengan menggunakan teknik purposive sampling. Metode analisis data yang digunakan adalah Customer Satisfaction Index (CSI) dan Importance Performance Analysis (IPA). Hasil penelitian yang diperoleh berdasarkan metode CSI menunjukkan bahwa secara keseluruhan tingkat kep ua san pelanggan Gojek di Kota Bandung termasuk dalamkategori "Puas". Hasil perhitungan berdasarkan metode IPA terdapat terdapat tiga item yang perlu diperbaiki, enam belas item yang perlu dipertahankan dan tiga belas item yang perlu dikurangi intensitasnya oleh Gojek. 


\section{PENDAHULUAN \\ Latar Belakang}

Perkembangan zaman yang terus berkembang dengan pesat dan maju membuat teknologi yang semakin canggih, sarana transportasi, dan komunikasi pun menjadi mudah dalam mengikuti zaman. Hal ini berdampak pada aktivitas manusia yang semakin efektif, dan efisien. Pada setiap aktivitas manusia yang beragam dibutuhkan alat bantu/penunjang untuk melakukan aktivitasnya seperti contoh alat transportasi. Terobosan terbaru yang muncul pada era masa kini adalah pemesanan jasa transportasi melalui aplikasi online yang berguna untuk memudahkan masyarakat sekitar dalam melakukan mobilitas. Aplikasi tersebut dapat digunakan oleh pengguna hanya dengan memiliki smartphone sebagai perangkat online untuk memesan alat transportasi yang dibutuhkan seperti mobil/sepeda motor. Pemesanan melalui aplikasi ini dapat dilakukan dimana saja dan kapan saja.

Alat transportasi yang paling sering digunakan oleh masyarakat di Indonesia adalah sepeda motor. Hal ini dikarenakan angkutan sepeda motor atau ojek dapat berfungsi sebagai moda transportasi alternatif lain yang mampu untuk menerobos kemacetan di kota-kota besar (Amajida, 2016). Oleh karena itu, banyak bermunculan perusahaan jasa transportasi online seperti Gojek. Gojek merupakan salah satu perusahaan jasa transportasi online yang kini telah hadir di 167 kota dan kabupaten di Indonesia termasuk Kota Bandung (Gojek, 2018) sehingga pertumbuhan aplikasi transportasi online di Kota Bandung semakin tumbuh dengan pesat (Kompas, 2018). Berdasarkan laporan Bank Pembangunan Asia (Asian Development Bank/ADB) yang dirilis pada september 2019, dikatakan bahwa ditingkat Asia Kota Bandung berada di urutan ke-14, DKI Jakarta berada di urutan ke-17, lalu Surabaya di urutan ke- 20 sebagai kota termacet. Oleh karena itu, Kota Bandung tercatat sebagai kota termacet se-Indonesia melebihi Kota Jakarta dan Surabaya (CNN Indonesia, 2019).

Fitur dan layanan yang Gojek berikan kepada masyarakat membuat semakin bertambah banyak pengguna pada setiap tahunnya. Namun belakangan ini banyak keluhan kepada Gojek yang diadukan oleh banyak pelanggan melalui Twitter dibandingkan dengan melalui Instagram atau sosial media lainnya. Hal ini dikarenakan akun resmi Gojek Indonesia pada Twitter lebih sering aktif sehingga respon dari Gojek cepat tanggap. Beberapa jenis keluhan yang sering diadukan melalui akun resmi twitter @ gojekindonesia adalah sebagai berikut:

Tabel 1. Jenis - Jenis Keluhan Pelanggan

\begin{tabular}{|c|l|}
\hline No & \multicolumn{1}{|c|}{ Jenis - Jenis Keluhan Pelanggan } \\
\hline 1. & $\begin{array}{l}\text { Pelanggan mendapatkan panggilan tidak dikenal yang } \\
\text { mengatasnamakan Gojek untuk memberikan undian, hadiah } \\
\text { uang, dan mendapatkan voucher Go-Pay yang bernilai jutaan. }\end{array}$ \\
\hline 2. & $\begin{array}{l}\text { Driver Gojek sering membatalkan pesanan pelanggan pada } \\
\text { layanan Go-Ride, Go-Car, dan Go-Food. }\end{array}$ \\
\hline 3. & $\begin{array}{l}\text { Melakukan top up Go-Pay tetapi tidak masuk saldo Go-Pay ke } \\
\text { akun pelanggan. }\end{array}$ \\
\hline
\end{tabular}


Lanjutan Tabel 1. Jenis - Jenis Keluhan Pelanggan

\begin{tabular}{|c|l|}
\hline No & \multicolumn{1}{|c|}{ Jenis - Jenis Keluhan Pelanggan } \\
\hline 4. & $\begin{array}{l}\text { Pelanggan melakukan pemesanan makanan/minuman pada Go- } \\
\text { Food tetapi tidak datang atau tidak sesuai pesanan dan sudah } \\
\text { melakukan pembayaran kepada driver Gojek. }\end{array}$ \\
\hline 5. & $\begin{array}{l}\text { Pelanggan melakukan pengiriman barang melalui Go-Send } \\
\text { tetapi barang tidak sampai/diambil oleh driver Gojek. }\end{array}$ \\
\hline 6. & $\begin{array}{l}\text { Saldo Go-Pay pelanggan yang senilai ratusan ribu ditarik oleh } \\
\text { driver Gojek tanpa melakukan transaksi apapun }\end{array}$ \\
\hline 7. & $\begin{array}{l}\text { Pelanggan menemukan beberapa driver yang memiliki sikap } \\
\text { tidak sopan santun pada saat mengirimkan pesan untuk } \\
\text { mengkonfirmasi orderan maupun pada layanan Go-Ride/Go- } \\
\text { Car disaat perjalanan sedang berlangsung. }\end{array}$ \\
\hline
\end{tabular}

Sumber: Twitter (2019-2020)

Keluhan pada Tabel 1 menunjukkan bahwa terdapat banyak masalah yang terjadi pada setiap layanan dan jasa yang ditawarkan Gojek yaitu modus penipuan yang mengatasnamakan Gojek Indonesia kepada pelanggan. Modus penipuan yang dilakukan kepada pelanggan adalah seperti modus untuk memberikan undian, hadiah uang, mendapatkan voucher Go-Pay yang bernilai jutaan, melakukan top up Go-Pay tetapi tidak masuk ke akun pelanggan dan juga saldo Go-Pay pelanggan yang senilai ratusan ribu ditarik oleh driver tanpa melakukan transaksi apapun. Modus ini dilakukan dengan cara menghubungi pelanggan via telepon ataupun langsung dari aplikasi pada kasus saldo Go-Pay yang hilang tanpa transaksi apapun. Sebagian pelanggan juga mengatakan bahwa terdapat penipu yang menggunakan kata-kata kasar dan memberikan ancaman seperti melakukan telepon kepada nomer pelanggan dengan cara berulang. Masalah selanjutnya yaitu pada pemesanan makanan atau minuman pada Go-Food oleh konsumen yang tidak kunjung datang atau tidak sesuai pesanan tetapi sudah melakukan pembayaran. Konsumen juga mengeluhkan pengiriman barang melalui Go-Send yang tidak sampai barangnya atau dibawa oleh driver. Lalu seringnya driver Gojek membatalkan pemesanan konsumen pada layanan Go-Ride, Go-Car, maupun Go-Food dan juga beberapa driver Gojek yang memiliki sikap tidak sopan kepada konsumen. Masalah yang terjadi sangat meresahkan banyak pelanggan Gojek dan dapat mencemarkan nama baik Gojek Indonesia apabila terus berulang serta pelanggan yang merasa nyaman dan aman terhadap layanan Gojek dapat beralih menggunakan jasa transportasi online lainnya. Oleh karena itu, Gojek sebagai perusahaan layanan jasa transportasi yang berbasis online sangat perlu untuk meningkatkan kualitas pelayanan yang baik dan dapat menanggulangi keluhan-keluhan yang diadukan oleh pelanggan agar terciptanya kepuasan pelanggan dan loyalitas pelanggan.

Penelitian ini menggunakan metode Customer Satisfaction Index (CSI) untuk menentukan tingkat kepuasan pelanggan secara menyeluruh dengan pendekatan yang mempertimbangkan tingkat kepentingan dari atribut-atribut yang diukur (Syukri, 2014) dan metode Importance Performance Analysis (IPA) untuk mengetahui tingkat kepuasan konsumen serta hal-hal apa saja yang perlu diperbaiki dan dipertahankan atas pelayanan yang telah diberikan, sehingga dapat menjadi dasar untuk meningkatkan 
kepuasan konsumen (Lupiyoadi, Rambat dan Ikhsan, \& Ridho Bramulya, 2015). Berdasarkan fenomena yang ada, peneliti tertarik untuk menggunakan Gojek sebagai objek dari penelitian dengan mengangkat judul "Penerapan Customer Service Index (CSI) dan Importance Performance Analysis (IPA) Pada Kualitas Pelayanan Gojek (Studi Pada Pelanggan Gojek di Kota Bandung)."

\section{Rumusan Masalah}

Berdasarkan latar belakang diatas, maka rumusan masalah dalam penelitian adalah sebagai berikut:

1. Bagaimana tingkat kepuasan pelanggan Gojek di Kota Bandung melalui analisis Customer Satisfaction Index (CSI)?

2. Atribut-atribut apa saja yang perlu dipertahankan, diperbaiki dan dikurangi intensitasnya untuk meningkatkan kepuasan pelanggan Gojek di Kota Bandung melalui analisis Importance Performance Analysis (IPA)?

\section{Tujuan Penelitian}

Tujuan dalam penelitian ini asalah sebagai berikut.

1. Untuk mengetahui tingkat kepuasan pelanggan Gojek di Kota Bandung melalui analis is Customer Satisfaction Index (CSI).

2. Untuk mengetahui atribut-atribut yang perlu dipertahankan, diperbaiki dan dikurangi intensitasnya untuk meningkatkan kepuasan pelanggan Gojek di Kota Bandung melalui analisis Importance Performance Analysis (IPA).

\section{KAJIAN PUSTAKA \\ Jasa}

Jasa adalah setiap tindakan atau kegiatan yang dapat ditawarkan oleh satu pihak kepada pihak lain, pada dasarnya tidak berwujud dan tidak mengakibatkan perpindahan kepemilikan apapun. Produksi jasa mungkin berkaitan dengan produk fisik atau tidak (Lupiyoadi, 2014).

\section{Kualitas Pelayanan}

Kualitas pelayanan yaitu memberikan kesempurnaan pelayanan yang dilakukan oleh penyedia layanan dalam memenuhi kebutuhan dan keinginan pelanggan serta ketepatan penyampaiannya untuk mengimbangi harapan pelanggan. Kualitas pelayanan menjadi hal penting yang harus diperhatikan serta dimaksimalkan agar mampu bertahan dan tetap dijadikan pilihan oleh pelanggan (Sembiring, Suharyono, \& Kusumawati, 2014).

\section{Transportasi}

Transportasi adalah kegiatan pemindahan barang (muatan) dan penumpang dari suatu tempat ke tempat lain. Dalam transportasi ada dua unsur yang terpenting yaitu pemindahan/pergerakan (movement) dan secara fisik mengubah tempat dari barang (comoditi) dan penumpang ke tempat lain (Salim, 2000). 


\section{Kualitas Layanan Jasa Transportasi}

Menurut Poliaková (2010) kriteria kualitas layanan dari jasa transportasi terdiri dari delapan kriteria, yaitu:

1. Availability (Ketersediaan)

Tingkat layanan yang ditawarkan dalam hal geografi, moda transportasi dan frekuensi waktu (jam beroperasi). Hubungan dengan alat transportasi lain terkait ketersediaan jasa transportasi lainnya untuk menggantikan apabila jasa transportasi yang dipesan tidak dapat melayani.

2. Access (Akses)

Aksesibilitas geografik terkait luas distribusi jaringan jasa transportasi. Luas distribusi jaringan jasa transportasi adalah cakupan wilayah yang mampu dilayani oleh jasa transportasi tersebut. Aksesibilitas waktu terkait jam operasional perusahaan untuk melayani pesanan pelanggan. Frekuensi layanan terkait dengan jumlah layanan yang tersedia untuk digunakan oleh pelanggan.

3. Information (Informasi)

Ketersediaan informasi layanan, pelayanan pelanggan, sign at stops, dan biaya perjalanan. Ketersediaan layanan terkait jenis dan jumlah layanan yang ditawarkan kepada pelanggan. Pelayanan pelanggan terkait cara yang dapat dilakukan pelanggan untuk menghubungi layanan pelanggan. Sign at stops terkait dengan ketersediaan informasi tentang pemberhentian kendaraan bagi pelanggan. Biaya perjalanan terkait harga yang harus dibayarkan pelanggan untuk setiap layanan yang ditawarkan perusahaan.

4. Time (Waktu)

Akurasi kedatangan atau keberangkatan, frekuensi keberangkatan dan waktu perjalanan. Akurasi kedatangan atau keberangkatan terkait pada ketepatan waktu yang dijanjikan oleh penyedia jasa kepada pelanggan. Frekuensi keberangkatan terkait dengan jumlah kendaraan yang tersedia untuk digunakan pelanggan. Waktu perjalanan merupakan waktu yang dihabiskan konsumen saat mengkonsumsi layanan.

5. Customer Service (Layanan Pelanggan)

Kritik dan saran, menjawab pertanyaan, pemasaran dan akses personnel. Kritik dan saran terkait kemampuan perusahaan untuk menerima dan mengumpulkan serta menganalisis keluhan, kritik maupun saran dari pelanggan. Menjawab pertanyaan terkait kemampuan perusahaan untuk menjawab pertanyaan yang diajukan oleh pelanggan maupun memberikan solusi bagi keluhan pelanggan. Pemasaran terkait dengan kegiatan pemasaran yang dilakukan oleh perusahaan untuk menarik pelanggan. Akses personnel terkait hubungan perusahaan dengan pelanggan apabila ada keluhan maupun saran yang dilakukan secara pribadi (bukan secara umum).

6. Comfort (Kenyamanan)

Perlindungan terhadap cuaca, kebersihan pada tempat pemberhentian, kebersihan kendaraan, tempat pemberhentian yang tidak berisik, menyalakan kendaraan \& pengereman serta gaya berkendara. Perlindungan terhadap cuaca terkait alat transportasi maupun atribut yang disediakan perusahaan untuk melindungi konsumen dari faktor cuaca. Kebersihan pada tempat pemberhentian 
terkait dengan kondisi tempat menunggu bagi pelanggan. Kebersihan kendaraan terkait dengan kondisi kendaraan yang digunakan untuk melayani pelanggan. Tempat pemberhentian yang tidak berisik terkait pada suasana tempat pemberhentian. Menyalakan kendaraan \& pengereman terkait dengan sikap mengemudi pengendara dalam menggunakan kendaraannya saat sedang di perjalanan. Gaya berkendara terkait dengan cara mengemudi pengendara yang dapat menciptakan perjalanan yang nyaman bagi pelanggan.

7. Safety (Keamanan)

Gaya berkendara, lampu kendaraan, pengawasan area, elemen berkendara dan pengawasan polisi. Gaya berkendara terkait dengan sikap maupun cara pengendara mengemudikan kendaraannya saat sedang diperjalanan. Lampu kendaraan yang berfungsi untuk menjadi penerangan ketika perjalanan pada malam hari maupun cuaca buruk. Pengawasan area terkait dengan pengendalian terhadap kondisi jalan yang merupakan jalur yang dilewati pengendara dan pelanggan saat menerima layanan. Elemen berkendara terkait dengan atribut yang digunakan pengendara maupun pelanggan saat proses konsumsi jasa terjadi. Pengawasan polisi atau pengendara terkait dengan pengawasan yang dilakukan oleh pihak berwajib maupun perusahaan saat proses layanan berlangsung.

8. Environment (Lingkungan)

Penggunaan sumber daya energi, tingkat emisi, kebisingan kendaraan dan produksi bau atau debu. Penggunaan sumber daya energi terkait dengan konsumsi bahan bakar yang digunakan untuk sumber energi bagi alat transportasi yang digunakan dan penggunaan kendaraan ramah lingkungan. Tingkat emisi terkait dengan emisi yang dihasilkan dari alat transportasi yang digunakan untuk melayani pelanggan dalam menjaga pencemaran polusi udara. Kebisingan kendaraan terkait suara yang ditimbulkan kendaraan.

\section{Kepuasan Pelanggan}

Kepuasan pelanggan adalah perasaan senang atau kecewa seseorang yang dihasilkan dari membandingkan produk atau kinerja pelayanan yang dirasakan terhadap ekspektasi. Jika kinerja produk atau layanan tidak mencapai harapan maka pelanggan tidak puas. Tetapi jika produk atau layanan melebihi harapan maka pelanggan akan puas (Kotler \& Keller, 2016).

\section{Customer Satisfaction Index (CSI)}

Metode Customer Satisfaction Index (CSI) digunakan untuk mengetahui tingkat kepuasan konsumen. Metode ini memiliki beberapa keunggulan antara lain efisiensi (tidak hanya indeks kepuasan tetapi sekaligus memperoleh informasi yang berhubungan dengan dimensi/atribut yang perlu diperbaiki), mudah digunakan dan sederhana serta menggunakan skala yang memiliki sensitivitas dan reliabilitas cukup tinggi (Anggraini, Deoranto, \& Ikasari, 2013). Pengukuran Customer Satisfaction Index (CSI) dilakukan untuk mengetahui kepuasan pelanggan dan dijadikan acuan dalam menentukan sasaran-sasaran di masa yang akan datang (Indrajaya, 2018). 


\section{Importance Performance Analysis (IPA)}

Importance Performance Analysis (IPA), merupakan alat bantu dalam menganalisis atau yang digunakan untuk membandingkan sampai sejauh mana antara kinerja/pelayanan yang dapat dirasakan oleh pengguna jasa dibandingkan terhadap tingkat kepuasan yang diinginkan. Untuk mengukur tingkat kepentingan dan tingkat kepuasan/kinerja terhadap jawaban responden, digunakan skala 5 tingkat (Skala Likert) (Idris, 2009). Sedangkan menurut Wong, Hideki \& George (2011, p. 21) IPA merupakan sebuah alat evaluasi yang digunakan untuk mengetahui tingkat kepuasan pelanggan dan mengetahui item-item yang diprioritaskan untuk diperbaiki oleh perusahaan agar dapat dijadikan sebagai panduan dalam pengembangan bagi perusahaan. Penggunaan metode Importance-Performance Analysis adalah dalam mengukur tingkat kepuasan pelayanan jasa yang masuk pada kuadran-kuadran pada peta Importance-Performance Matrix (Indrajaya, 2018).

\section{Kerangka Pemikiran}

\section{Gambar 1. Kerangka Pemikiran}

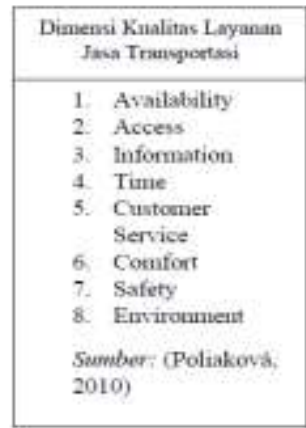

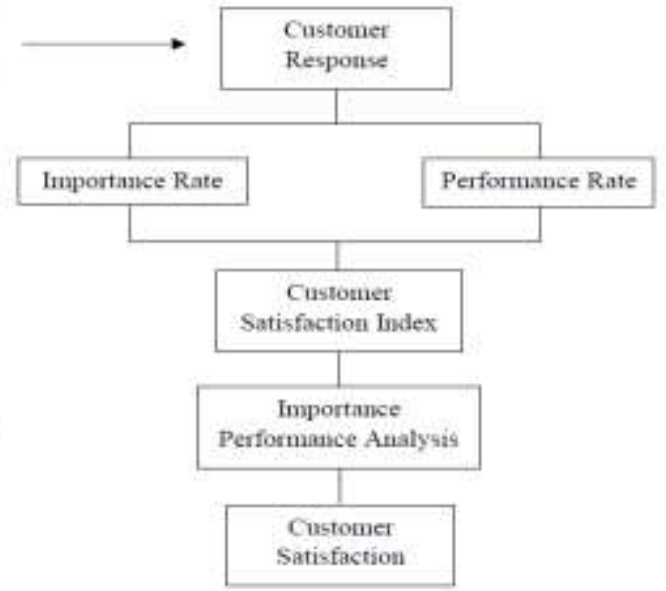

Sumber: Diadopsi dari model kerangka pemikiran (Widi., Utomo, \& Wijaya, 2013)

\section{METODE PENELITIAN \\ Jenis Penelitian}

Jenis penelitian ini menggunakan metode penelitian kuantitatif yang digunakan untuk meneliti pada populasi atau sampel tertentu, pengumpulan data menggunakan instrumen penelitian, analisis data bersifat kuantitatif/statistik, dengan tujuan untuk menguji hipotesis yang telah ditetapkan (Sugiyono, 2013).

\section{Tempat, Waktu dan Subjek Penelitian}

Penelitian ini dilakukan di Bandung dan dilakukan selama 7 bulan dari bulan Oktober 2019 - April 2020. Subjek pada penelitian ini yaitu Gojek dan yang menjadi sampelnya merupakan pelanggan yang menggunakan layanan pada Gojek di Kota Bandung. 


\section{Teknik Pengumpulan Data}

Teknik pengambilan sampel dalam penelitian ini ialah teknik sampling non probability sampling atau disebut juga purposive sampling. Jumlah sampel sebanyak 400 responden. Teknik pengumpulan dengan menggunakan kuesioner sebagai data primer.

\section{Teknik Analisis Data}

Teknik analisis data dilakukan dengan menggunakan metode Customer Satisfaction Index (CSI) dan Importance Performance Analysis (IPA). Pengolahan data pada penelitian ini menggunakan software statistic yaitu SPSS 24.0 for windows.

\section{HASIL PENELITIAN DAN PEMBAHASAN Hasil Penelitian \\ Customer Satisfaction Index (CSI)}

Berdasarkan perhitungan dan pengolahan data dengan menggunakan metode Customer Satisfaction Index (CSI) hasil yang diperoleh dibagi menjadi dua bagian yaitu berdasarkan delapan kriteria kualitas layanan untuk transportasi dan berdasarkan nilai Customer Satisfaction Index (CSI) secara keseluruhan. Interpretasi nilai CSI disesuaikan dengan kriteria yang dapat ditentukan sebagai berikut:

Tabel 2. Interpretasi Customer Satisfaction Index

\begin{tabular}{|l|l|l|}
\hline No & $\begin{array}{l}\text { Nilai CSI } \\
(\%)\end{array}$ & $\begin{array}{l}\text { Keterangan } \\
(\text { CSI })\end{array}$ \\
\hline 1 & $81 \%-100 \%$ & Sangat Puas \\
\hline 2 & $66 \%-80.99 \%$ & Puas \\
\hline 3 & $51 \%-65.99 \%$ & Cukup Puas \\
\hline 4 & $35 \%-50.99 \%$ & Kurang Puas \\
\hline 5 & $0 \%-34.99 \%$ & Tidak Puas \\
\hline
\end{tabular}

Sumber: Widodo \& Sutopo (2019)

Tabel 2 menunjukkan bahwa Nilai Customer Satisfaction Index (CSI) berdasarkan delapan kriteria kualitas layanan memiliki enam kriteria yaitu Availability, Time, Customer Service, Comfort, Safety, dan Environment yang mendapatkan nilai CSI yang berada pada rentang 66\% - 80,99\% dan termasuk dalam kategori "Puas". Lalu untuk kriteria Information diperoleh nilai CSI yang berada pada rentang 51\% - 65,99 \% dan termasuk dalam kategori "Cukup Puas". Kemudian untuk kriteria Access diperoleh nilai CSI yang berada pada rentang 81\% - 100\% dan termasuk dalam kategori "Sangat Puas". Selanjutnya pada Nilai Customer Satisfaction Index (CSI) secara keseluruhan, diperoleh nilai sebesar $73,54 \%$ yang berada pada rentang 66\% - 80,99\% dan termasuk dalam kategori "Puas". Oleh karena itu, pelayanan Gojek masih dirasakan belum maksimal secara keseluruhan dan diperlukannya perbaikan terhadap indikator-indikator dalam kualitas layanan oleh pihak manajemen Gojek sehingga diharapkan dapat memberikan tingkat kepuasan pelanggan yang lebih tinggi hingga mencapai kategori "Sangat Puas" dalam indeks kepuasan pelanggan. 


\section{Importance Performance Analysis (IPA)}

Perhitungan menggunakan metode Importance Performance Analysis (IPA) bertujuan untuk melihat indikator apa saja yang harus diperbaiki, diperhatikan, dikurangi intensitasnya dan ditambahkan berdasarkan diagram kartesius yang terbagi menjadi empat kuadran:

Gambar 2. Diagram Kartesius Importance Performance Analysis (IPA)

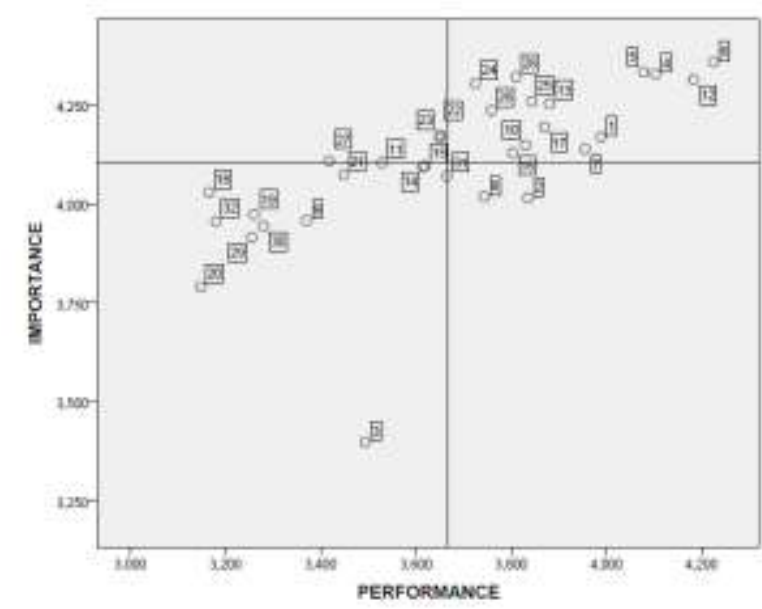

Sumber: Hasil Pengolahan Data (2019)

Gambar 2 menunjukan hasil olahan data diagram kartesius Importance Performance Analysis (IPA) Gojek di Kota Bandung. Berikut adalah hasil pemetaan dari keempat kuadran dalam diagram kartesius:

1. Kuadran I

Kuadran I merupakan kuadran dengan prioritas tinggi. Atribut-atribut pada kuadran ini dianggap penting bagi pelanggan tetapi kinerja pelayanannya tidak sesuai dengan yang diharapkan oleh pelanggan. Atribut-atribut yang termasuk pada kuadran ini adalah sebagai berikut:

a. Pengendara Gojek memiliki pengalaman dalam mengoperasikan kendaraannya dengan baik (no. item 22).

b. Pengendara Gojek mengemudikan kendaraannya dengan baik sehingga menciptakan perjalananan yang nyaman (no. item 23).

c. Pengendara Gojek menggunakan atribut (helm dan jaket Gojek) dengan lengkap dan membawa perlengkapan untuk pelanggan seperti Shower Cap dan helm (no. item 27).

Ketiga atribut diatas harus dijadikan sebagai prioritas utama bagi pihak Gojek untuk dilakukan perbaikan kinerja agar dapat meningkatkan kepuasan pelanggan.

2. Kuadran II

Kuadran II mencakup atribut-atribut yang dianggap sudah sesuai dengan harapan pelanggan terhadap kinerja dari pihak Gojek. Atribut-atribut yang termasuk pada kuadran ini adalah sebagai berikut:

a. Penggunaan aplikasi gojek yang selalu dapat digunakan kapan saja ketika pelanggan ingin melakukan pemesanan (no. item 1). 
b. Penggunaan layanan dan fitur Gojek dapat diakses di seluruh wilayah khususnya pada Kota Bandung (no. item 4).

c. Layanan dan fitur Gojek dapat diakses 24 jam pada setiap harinya (no. item 5).

d. Layanan dan fitur Gojek dapat diakses berulang kali dalam sehari (no item 6).

e. Gojek memberikan informasi yang jelas mengenai layanan yang ditawarkan (no. item 7).

f. Harga yang akan dibebankan kepada pelanggan disesuaikan dengan jarak yang ditempuh dan tertera pada aplikasi (no. item 10).

g. Penggunaan layanan dan fitur Gojek oleh pelanggan dapat digunakan berulang kali dalam sehari (no.item 12).

h. Perjalanan menggunakan layanan Go-Ride pada Gojek dapat mempersingkat waktu ketika macet (no.item 13).

i. Gojek memberikan informasi tentang promo yang sedang berlaku kepada pelanggan (no.item 16).

j. Pelanggan dapat mengadukan keluhan, kritik, dan saran melalui aplikasi Gojek, email dan call center (no. item 17).

k. Pengendara Gojek mematuhi peraturan lalu lintas yang berlaku (no. item 24).

1. Kendaraan yang digunakan pengendara Gojek memiliki lampu kendaraan yang berfungsi dengan baik untuk perjalanan pada malam hari dan ketika cuaca buruk (hujan dan berkabut) (no. item 25).

m. Pengendara Gojek memilih jalur dan jalan yang aman untuk dilewati (no. item 26).

n. Pelanggan yang menggunakan layanan dan fitur Gojek akan selalu diawasi oleh pihak Gojek maupun pihak berwenang untuk menjaga keselamatan pelanggan maupun pengendara (no. item 28).

Atribut-atribut yang berada pada kuadran II merupakan atribut harus dipertahankan oleh pihak Gojek dikarenakan pelaksanaan kinerja dari Gojek sudah sesuai dengan harapan pelanggan.

3. Kuadran III

Kuadran III merupakan kudran dengan prioritas yang rendah. Atribut-atribut yang berada pada kuadran ini dianggap kurang penting karena kinerjanya yang tidak terlalu baik. Atribut-atribut yang termasuk pada kuadran ini adalah sebagai berikut:

a. Saat ini Gojek mengeluarkan layanan dan fitur tambahan pada Go-Ride yaitu Go-Blue Bird. Dimana Gojek bekerjasama dengan taksi Blue Bird (no. item 3).

b. Gojek menyediakan tempat penjemputan yang resmi bagi pelanggan seperti Gojek Corner pada stasiun/bandara (no. item 9).

c. Gojek datang tepat waktu ketika pelanggan sudah melakukan pemesanan (no. item 11).

d. Gojek selalu menanggapi keluhan, kritik dan saran dari pelanggan (no. item 14).

e. Gojek dapat menjawab pertanyaan dari pelanggan dengan baik (no. item 15).

f. Pengendara Gojek menyediakan jas hujan dan masker bagi pelanggan pada layanan Go-Ride (no. item 18). 
g. Titik penjemputan resmi atau Gojek Corner yang disediakan untuk menunggu bagi pelanggan pada stasiun/bandara memiliki tempat yang bersih (no. item 19).

h. Titik penjemputan resmi atau Gojek Corner yang disediakan untuk menunggu bagi pelanggan pada stasiun/bandara memiliki tempat yang tidak berisik (no. item 20).

i. Kendaraan yang dipakai oleh layanan Gojek selalu bersih (no. item 21).

j. Gojek menggunakan kendaraan ekologis yaitu kendaraan yang ramah lingkungan (no. item 29).

k. Kendaraan yang digunakan Gojek memenuhi ambang batas emisi gas buang kendaraan untuk menghindari pencemaran polusi udara (no. item 30).

1. Kendaraan yang digunakan oleh pengendara Gojek tidak menyebabkan kebisingan (no. item 31).

m. Kendaraan yang digunakan oleh pengemudi Gojek tidak menyebabkan polusi udara (no. item 32).

\section{Kuadran IV}

Kuadran IV mencakup atribut-atribut yang tingkat kepentingannya dianggap rendah oleh pelanggan tetapi kinerja pelayanan yang diberikan sudah sangat baik. Atribut-atribut yang termasuk pada kuadran ini adalah

a. Selalu ada minimal satu kendaraan yang dapat digunakan seperti contoh pada Go-Ride untuk setiap layanan yang dipesan oleh pelanggan (no. item 2).

b. Komunikasi yang dilakukan dengan pelanggan perihal layanan dan fitur dapat dilakukan melalui media media sosial dan call center (no. item 8).

Atribut-atribut yang berada pada kuadran IV merupakan atribut yang memiliki tingkat kepentingan rendah namun tingkat pelaksanaan kinerja yang tinggi dari pihak Gojek.

\section{KESIMPULAN DAN SARAN \\ Kesimpulan}

Berdasarkan hasil penelitian dan pengolahan data, terdapat beberapa kesimpulan yang dapat diambil untuk menjawab rumusan masalah pada penelitian ini yaitu sebagai berikut:

1. Berdasarkan hasil Customer Satisfaction Index (CSI) secara keseluruhan diperoleh tingkat kepuasan pelanggan Gojek terhadap layanan yang diberikan Gojek kepada pelanggan adalah sebesar 73,54\%. Dari hasil CSI tersebut diperoleh kriteria interpretasi nilai CSI menurut Widodo \& Sutopo (2018) yang berada pada tingkat kategori "Puas".

2. Berdasarkan hasil Importance Performance Analysis (IPA) diperoleh empat kuadran sebagai penentu atribut-atribut apa saja yang perlu diperbaiki, ditingkatkan, dikurangi intensitasnya dan dipertahankan. Pada kuadran I terdapat tiga atribut yang memiliki tingkat kepentingan dengan prioritas tinggi bagi pelanggan dan perlu diperbaiki dikarenakan kinerja layanan Gojek dianggap tidak sesuai dengan yang diharapkan oleh pelanggan. Atribut-atribut tersebut adalah pengendara Gojek memiliki pengalaman dalam mengoperasikan kendaraannya dengan baik, Pengendara Gojek mengemudikan kendaraannya dengan baik sehingga 
menciptakan perjalananan yang nyaman dan Pengendara Gojek menggunakan atribut (helm dan jaket Gojek) dengan lengkap dan membawa perlengkapan untuk pelanggan seperti Shower Cap dan helm. Lalu pada kuadran II terdapat empat belas atribut yang kinerja layanannya dianggap sudah sesuai dengan harapan pelanggan Gojek sehingga harus dipertahankan dan ditingkatkan oleh pihak manajemen Gojek. Atribut-atribut tersebut adalah Penggunaan aplikasi gojek yang selalu dapat digunakan kapan saja ketika pelanggan ingin melakukan pemesanan, Penggunaan layanan dan fitur Gojek dapat diakses di seluruh wilayah khususnya pada Kota Bandung, Layanan dan fitur Gojek dapat diakses 24 jam pada setiap harinya, Layanan dan fitur Gojek dapat diakses berulang kali dalam sehari, Gojek memberikan informasi yang jelas mengenai layanan yang ditawarkan, Harga yang akan dibebankan kepada pelanggan disesuaikan dengan jarak yang ditempuh dan tertera pada aplikasi, Penggunaan layanan dan fitur Gojek oleh pelanggan dapat digunakan berulang kali dalam sehari, Perjalanan menggunakan layanan Go-Ride pada Gojek dapat mempersingkat waktu ketika macet, Gojek memberikan informasi tentang promo yang sedang berlaku kepada pelanggan, Pelanggan dapat mengadukan keluhan, kritik, dan saran melalui aplikasi Gojek, email dan call center, Pengendara Gojek mematuhi peraturan lalu lintas yang berlaku, Kendaraan yang digunakan pengendara Gojek memiliki lampu kendaraan yang berfungsi dengan baik untuk perjalanan pada malam hari dan ketika cuaca buruk (hujan dan berkabut), Pengendara Gojek memilih jalur dan jalan yang aman untuk dilewati, Pelanggan yang menggunakan layanan dan fitur Gojek akan selalu diawasi oleh pihak Gojek maupun pihak berwenang untuk menjaga keselamatan pelanggan maupun pengendara. Kemudian pada kuadran III terdapat tiga belas atribut yang dianggap oleh pelanggan memiliki tingkat kepentingan dengan prioritas rendah dan tingkat kinerja yang kurang baik oleh karena itu diperlukannya pengurangan intensitas pada atribut tersebut oleh pihak manajemen Gojek. Atribut-atribut tersebut adalah Saat ini Gojek mengeluarkan layanan dan fitur tambahan pada GoRide yaitu Go-Blue Bird. Dimana Gojek bekerjasama dengan taksi Blue Bird, Gojek menyediakan tempat penjemputan yang resmi bagi pelanggan seperti Gojek Corner pada stasiun/bandara, Gojek datang tepat waktu ketika pelanggan sudah melakukan pemesanan, Gojek selalu menanggapi keluhan, kritik dan saran dari pelanggan, Gojek dapat menjawab pertanyaan dari pelanggan dengan baik, Pengendara Gojek menyediakan jas hujan dan masker bagi pelanggan pada layanan Go-Ride, Titik penjemputan resmi atau Gojek Corner yang disediakan untuk menunggu bagi pelanggan pada stasiun/bandara memiliki tempat yang bersih, Titik penjemputan resmi atau Gojek Corner yang disediakan untuk menunggu bagi pelanggan pada stasiun/bandara memiliki tempat yang tidak berisik, Kendaraan yang dipakai oleh layanan Gojek selalu bersih, Gojek menggunakan kendaraan ekologis yaitu kendaraan yang ramah lingkungan, Kendaraan yang digunakan Gojek memenuhi ambang batas emisi gas buang kendaraan untuk menghindari pencemaran polusi udara, Kendaraan yang digunakan oleh pengendara Gojek tidak menyebabkan kebisingan, Kendaraan yang digunakan oleh pengemudi Gojek tidak menyebabkan polusi udara. Kemudian pada kuadran IV terdapat dua atribut yang tingkat kepentingannya dianggap rendah oleh pelanggan tetapi kinerja pelayanan 
yang diberikan oleh Gojek sudah sangat baik sehingga perlu dipertahankan oleh pihak manajemen Gojek. Atribut-atribut tersebut adalah Selalu ada minimal satu kendaraan yang dapat digunakan seperti contoh pada Go-Ride untuk setiap layanan yang dipesan oleh pelanggan, Komunikasi yang dilakukan dengan pelanggan perihal layanan dan fitur dapat dilakukan melalui media media sosial dan call center.

\section{Saran}

Terdapat beberapa saran yang peneliti ajukan bagi perusahaan dan bagi peneliti selanjutnya sehingga dapat dijadikan solusi adalah sebagai berikut:

1. Saran Bagi Perusahaan

a. Berdasarkan pembahasan hasil penelitian, pihak manajemen Gojek dapat memperbaiki kinerja layanan dengan mengacu pada empat kuadran berdasarkan metode analisis Importance Performance Analysis (IPA) sehingga dapat diusulkan beberapa saran kepada perusahaan. Atribut-atribut yang perlu diperbaiki layanannya oleh pihak manajemen Gojek dapat dilihat dari kuadran I dikarenakan memiliki tingkat kepentingan (importance) yang tinggi tetapi tingkat kinerja (performance) perusahaan yang dianggap kurang baik bagi pelanggan. Berikut hal-hal yang perlu dilakukan oleh pihak manajemen Gojek sesuai dengan urutan prioritas atau tingkat kepentingan atribut:

b. Menyelenggarakan program pelatihan berkendara aman (safety training) secara berkala bagi para driver Gojek agar dapat memiliki pengalaman yang baik dalam mengoperasikan dan mengemudikan kendaraannya agar terciptanya perjalanan yang nyaman bagi pelanggan. Hal ini sangat diperlukan mengingat banyak pelanggan merasa kurang puas terhadap driver Gojek yang kurang berpengalaman dalam mengoperasikan dan mengemudikan kendaraannya sehingga menciptakan perjalanan yang kurang nyaman. Oleh karena itu, diperlukan perbaikan dan peningkatan layanan pada faktor kenyamanan dan keamanan.

c. Memberikan sosialisasi secara berkala kepada driver Gojek untuk menggunakan standar atribut pengemudi yang sudah ditentukan agar para driver Gojek mematuhi aturan tersebut. Standar atribut pengemudi tersebut yaitu penggunaan jaket Gojek, celana panjang, sepatu, sarung tangan, membawa jas hujan dan membawa dua helm standar nasional Indonesia. Kemudian diperlukan juga penambahan Shower Cap kedalam standar atribut pengemudi. Hal ini sangat diperlukan mengingat banyak pelanggan yang melihat driver Gojek yang tidak patuh dalam menggunakan atribut lengkap maupun tidak membawa atribut seperti helm bagi pelanggan. Apabila driver Gojek melanggarnya maka harus diberikan tindakan yang tegas untuk memberikan sanksi yang sesuai dengan Peraturan Menteri Perhubungan No. 12 tahun 2019.

2. Saran Bagi Peneliti Selanjutnya

Pada penelitian ini pembahasan yang diteliti hanya mencakup pada jasa yang diharapkan oleh pelanggan saja. Oleh karena itu, pada penelitian selanjutnya disarankan untuk meneliti pembahasan yang lain seperti persepsi manajemen atas 
harapan pelanggan, menjabarkan spesifikasi tentang kualitas jasa, melakukan komunikasi eksternal kepada pelanggan perihal penyampaian jasa yang dipersepsikan dan jasa yang diharapkan. Kemudian untuk saran lainnya adalah melakukan perluasan daerah penelitian seperti meneliti seluruh wilayah operasional Gojek di Indonesia, melakukan pengembangan terhadap item-item pernyataan berdasarkan penambahan layanan-layanan Gojek di masa yang akan datang, dan melakukan penelitian secara berkala agar memperoleh hasil yang lebih valid dan dapat dibandingkan dengan penelitian ini.

\section{DAFTAR PUSTAKA}

Amajida, F. D. 2016. Kreativitas Digital dalam Masyarakat Risiko Perkotaan: Studi Tentang Ojek Online "Go-jek" di Jakarta. INFORMASI Kajian Ilmu Komunikasi, Vol. 46 No.1, 115-128.

Anggraini, L. D., Deoranto, P., \& Ikasari, D. M. 2013. Analisis Persepsi Konsumen Menggunakan Metode Importance Performance Analysis dan Customer Satisfaction Index. Jurnal Fakultas Teknologi Industri Pertanian Universitas Brawijaya, 74-81.

CNN Indonesia. 2019. Bandung Kota Termacet se-Indonesia, Ragam Solusi Disiapkan. Retrieved October 10, 2019, from CNN Indonesia: https:/www.cnnindonesia.com/nasional/20191007205754-20-437595/bandungkota-termacet-se-indonesia-ragam-solusi-disiapkan

Gojek. 2018. Kini GO-JEK Hadir di 167 Kota dan Kabupaten Indonesia. Retrieved January 15, 2020, from Gojek: https://www.gojek.com/blog/gojek/go-jekdimana-mana/

Idris, Z. 2009. Kajian "Tingkat Kepuasan" Pengguna Angkutan Umum di DIY. dinamika TEKNIK SIPIL, Volume 9 Nomor 2, 189-196.

Indrajaya, D. 2018. Analisis Kualitas Pelayanan Terhadap Tingkat Kepuasan Konsumen Menggunakan Metode Importance Performance Analysis dan Customer Satisfaction Index Pada UKM Gallery. Jurnal IKRA-ITH Teknologi, Vol 2 No 3, 1-6.

Kompas. 2018. Hadirnya Go-Jek dan Pengaruhnya ke Perekonomian Bandung. Retrieved January 15, 2020, from Kompas.com: https://bandung.kompas.com/read/2018/12/28/15385761/hadirnya-go-jek-danpengaruhnya-ke-perekonomian-bandung?page $=$ all

Kotler , P., \& Keller, K. L. 2016. Marketing Management (15 ed.). United States of America: Pearson Education Limited.

Lupiyoadi, R. 2014. Manajemen Pemasaran Jasa (Edisi 3 ed.). Jakarta: Salemba Empat.

Lupiyoadi, Rambat dan Ikhsan, \& Ridho Bramulya. 2015. Praktikum Metode Riset. Jakarta: Salemba Empat.

Poliaková, A. 2010. Application Of The Customer Satisfaction Index (CSI) to Transport Service. Volume V,Number IV, 208-215.

Salim, A. 2000. Manajemen Transportasi. Jakarta: Raja Grafindo Persada.

Sembiring, I. J., Suharyono, \& Kusumawati, A. 2014. Pengaruh Kualitas Produk dan Kualitas Pelayanan Terhadap Kepuasan Pelanggan dalam Membentuk Loyalitas 
Pelanggan (Studi pada Pelanggan McDonald's MT.Haryono Malang). Jurnal Administrasi Bisnis (JAB), Vol. 15 No. 1 Oktober 2014, 1-10.

Sugiyono. 2013. Metode Penelitian Kuantitatif, Kualitatif, dan R\&D. Bandung: Alfabeta.

Syukri, S. A. 2014. Penerapan Customer Satisfaction Index (CSI) dan Analisis GAP Pada Kualitas Pelayanan Trans Jogja. Jurnal Ilmiah Teknik Industri, Vol. 13, No. 2, 103-111.

Twitter. 2019-2020. Keluhan Pada @gojekindonesia di Twitter. Retrieved from Twitter: https://twitter.com/gojekindonesia?lang=en

Widi., C. A., Utomo, W. H., \& Wijaya, A. F. 2013. Customer Satisfaction Analysis to Health Service by Servqual 5 Dimension Method and Customer Satisfaction Index. International Journal of Computer Applications (0975 - 8887), 17-21.

Widodo, S. M., \& Sutopo, J. 2018. Metode Customer Satisfaction Index (CSI) untuk Mengetahui Pola Kepuasan Pelanggan Pada E-Commerce Model Business To Customer. Jurnal Program Studi Informatika, Fakultas Teknologi Informasi dan Elektro Universitas Teknologi Yogyakarta, 1-8.

Wong, M. S., \& Nishimoto , H. 2011. The Use of Importance-Performance Analysis (IPA) in Evaluating Japan's E-government Services. Journal of Theoretical and Applied Electronic Commerce Research, 17-30. 